\title{
Students' Perception of the Effectiveness of Technology Assisted Online Education During COVID-19 Pandemic: An Empirical Study
}

Vinayachandra ${ }^{1}$, Geetha Poornima K. ${ }^{2}$, Rajeshwari M. ${ }^{3}$, \& Krishna Prasad K. ${ }^{4}$

${ }^{1}$ Research Scholar, College of Computer \& Information Sciences, Srinivas University, Mangalore, Karnataka, India and Assistant Professor, Dept of Computer Science, St

Philomena College, Puttur, Karnataka, India

Orcid ID: 0000-0002-9374-4871; E-mail: veeciashu@ gmail.com

${ }^{2}$ Research Scholar, College of Computer \& Information Sciences, Srinivas University, Mangalore, Karnataka, India and Assistant Professor, Dept of Computer Science, St

Philomena College, Puttur, Karnataka, India

Orcid ID: 0000-0001-9095-0349; E-mail: poornima.sanjay@gmail.com

${ }^{3}$ Research Scholar, College of Computer \& Information Sciences, Srinivas University, Mangalore, Karnataka, India and Assistant Professor, Dept of Computer Science, St

Philomena College, Puttur, Karnataka, India

Orcid ID: 0000-0001-9613-4967, E-mail: rajimuraleedhar@gmail.com

${ }^{4}$ College of Computer \& Information Sciences, Srinivas University, Mangalore, Karnataka, India

Orcid ID: 0000-0001-5282-9038; E-mail: krishnaprasadkcci@ srinivasuniversity.edu.in

Area/Section: Education Management.

Type of the Paper: Exploratory data analysis.

Type of Review: Peer Reviewed as per $|\mathrm{C}| \mathrm{O}|\mathrm{P}| \mathrm{E} \mid$ guidance.

Indexed in: OpenAIRE.

DOI: https://doi.org/10.5281/zenodo.4922352

Google Scholar Citation: IJMTS

\section{How to Cite this Paper:}

Vinayachandra, Geetha Poornima K., Rajeshwari, M. \& Krishna Prasad, K. (2021). Students' Perception of the Effectiveness of Technology Assisted Online Education During COVID-19 Pandemic: An Empirical Study. International Journal of Management, Technology, and Social Sciences (IJMTS), 6(1), 203-225. DOI: https://doi.org/10.5281/zenodo.4922352.

International Journal of Management, Technology, and Social Sciences (IJMTS)

A Refereed International Journal of Srinivas University, India.

CrossRef DOI: https://doi.org/10.47992/IJMTS.2581.6012.0141

(C) With Author.

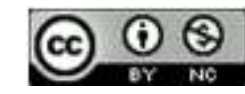

This work is licensed under a Creative Commons Attribution-Non-Commercial 4.0 International License subject to proper citation to the publication source of the work.

Disclaimer: The scholarly papers as reviewed and published by the Srinivas Publications (S.P.), India are the views and opinions of their respective authors and are not the views or opinions of the SP. The SP disclaims of any harm or loss caused due to the published content to any party. 


\title{
Students' Perception of the Effectiveness of Technology Assisted Online Education During COVID-19 Pandemic: An Empirical Study
}

\author{
Vinayachandra1, Geetha Poornima K. ${ }^{2}$, Rajeshwari M. ${ }^{3}$, \& Krishna Prasad K. ${ }^{4}$ \\ ${ }^{1}$ Research Scholar, College of Computer \& Information Sciences, Srinivas University, \\ Mangalore, Karnataka, India and Assistant Professor, Dept of Computer Science, St \\ Philomena College, Puttur, Karnataka, India \\ Orcid ID: 0000-0002-9374-4871; E-mail: veeciashu@ gmail.com \\ ${ }^{2}$ Research Scholar, College of Computer \& Information Sciences, Srinivas University, \\ Mangalore, Karnataka, India and Assistant Professor, Dept of Computer Science, St \\ Philomena College, Puttur, Karnataka, India \\ Orcid ID: 0000-0001-9095-0349; E-mail: poornima.sanjay@gmail.com \\ ${ }^{3}$ Research Scholar, College of Computer \& Information Sciences, Srinivas University, \\ Mangalore, Karnataka, India and Assistant Professor, Dept of Computer Science, St \\ Philomena College, Puttur, Karnataka, India \\ Orcid ID: 0000-0001-9613-4967, E-mail: rajimuraleedhar@gmail.com \\ ${ }^{4}$ College of Computer \& Information Sciences, Srinivas University, Mangalore, Karnataka, \\ India \\ Orcid ID: 0000-0001-5282-9038; E-mail: krishnaprasadkcci@ srinivasuniversity.edu.in
}

\begin{abstract}
Purpose: The whole calendar year 2020, as well as early indications, suggest, the year 2021, would be challenging for the global community. The COVID-19 pandemics spread through the world, affecting all facets of human endeavor, from industrial development to academic calendar re-adjustments at all educational institutions around the world. Stakeholders and administrators of academic institutions have no choice but to use internet technology, and therefore online learning, to continue academic activities in all institutions around the world. This paper aims to determine if students in higher educational institutions are happy with technology-assisted Online Education during COVID-19 Pandemic. The study used an online survey to find out how students are coping with online education, which has been around for years but is still not widely used, and how happy they are with it.
\end{abstract}

Methodology: Convenience sampling was employed to collect data for the analysis because it is a non-probability sampling methodology. The aim of using this method is to come up with hypotheses and conduct exploratory research on the topic. It also addresses budget and time constraints. As participants in this research, students from higher education institutions responded to the survey. Higher education students are preferred because they have already been exposed to technology, online platforms, and the ability to adapt, which is the essence of remote learning.

Findings/Result: The study's findings show that adding online education was a good decision since the majority of students surveyed supported it in this epidemic since it allowed them to complete their studies. In terms of satisfaction with online education, the study discovered that there is a gender divide. Students are self-sufficient in terms of the devices they use to take online classes, with a large percentage of students attending online classes using their smartphones. Synchronous delivery options, such as live classes, are not preferred by online educators. Female students spend more time on online education activities than male students. Finally, the study discovered that the most significant barrier to students participating in online education is a lack of internet connectivity in both rural and suburban settings.

Originality: This study examines how satisfied students are with technology-assisted online education at higher education institutions. The results of this study would be very useful to the 
administrators of higher education institutions in making potential emergency decisions about the planning of online learning services for students from various backgrounds.

Paper Type: Exploratory data analysis (EDA). This type is used to comprehend and summarize the contents of a dataset, usually to answer a particular query or to prepare for more sophisticated statistical modeling in subsequent stages of data analysis.

Keywords: Online Education, EDA, COVID-19, E-Learning, ChiSquare.

\section{INTRODUCTION :}

The Novel Corona Virus (COVID-19) pandemic has compelled the entire world to embrace virtual learning. While remote/online and distance learning have been used to maintain educational continuity in the past, as in the context of earthquakes, the current situation is unparalleled in scope. Speculation has now started as to what the long-term consequences will be, as well as what education would be like after COVID. For others, a return to the physical classroom's traditions is expected right away. Others, on the other hand, see the forced transition to online education as an opportunity to rethink how education can be provided. Adult learners pursuing higher education opportunities have historically regarded online education as an alternate direction [1]. The rise of the COVID-19 pandemic, on the other hand, has forced teachers and students throughout all levels of education to quickly adapt to virtual mode. In the early stages of the pandemic, the word "emergency remote teaching" was coined to explain the transient existence of this transition [2]. Due to further increases in the rate of infection, teaching was moved online, then went back to the actual on-campus mode, and then returned online again. In other words, instruction was provided by a hybrid of online and face-to-face delivery, with students having the option of attending either online or in person. In any case, teachers simply had to find how to put things together, taking into account the affordances and limitations of the particular learning environment to construct viable and meaningful learning experiences [3].

Fast forward to 2020, a slew of new educational innovations will have arisen, paving the way for mainstream adoption of distance learning. There are also many obstacles to overcome. The most noticeable one is the lack of or weaker Internet connectivity in certain regions, specifically in rural or remote areas[5]. Another issue is family members' conflicting demands for available home technology use. Thanks to the development of emerging technology, students and their families now have access to the facilities and resources they need to engage in online learning programs and complete coursespecific work [6]. In the pandemic-affected year 2020, available information and communication technology (ICT) and its facilities have been integrated into online education environments to improve teaching-learning experiences [7]. Virtual classrooms were developed using synchronous meeting applications and video conferencing tools like Zoom and Google Meet, which enabled experts from all over the world to enter and deliver classes. This also enabled learners to record virtual classroom activities to watch at their leisure, regardless of time, place, or phase. Virtual laboratories, simulated experiments, animated contents, and virtual field trips were developed in response to the need for handson, experiential learning. As a result, technology that was once primarily used for adult learning is now predominantly being used in the service of higher education students and, increasingly at primary and secondary school levels [8-9].

The widespread COVID-19 is additionally anticipated to have a long-term impact on lesson planning. Due to the pandemic's limitations, educators were able to explore new methods for teaching specific concepts [10]. Whereas the method of reconsidering instructional approaches has surged, it has given an uncommon opportunity to reevaluate techniques that way better advance learning inside the affordances and limitations of the online setting. Long Zoom sessions are seldom instructional fitting and are not steady with the mental concepts of how people learn, so more prominent variety in instructing and learning hones will proceed to call into address the esteem of 'seat time' as the standard on which educational credits are based. While students must interact, forcing them to interact just for the sake of interacting is neither encouraging nor beneficial [11-12].

While the boundaries between traditional and distance education have been blurring for decades, the pandemic has hastened the erasure of these lines [13]. Less single-mode and more multi-mode (and thus more teacher choices) is becoming the norm, thanks to improved infrastructure and developed skill sets that enable people to move across multiple delivery systems [14]. Best practices in hybrid or blended teaching and learning have served as a road map for new instructional delivery combinations that have arisen as a result of the shift to virtual learning. Multiple delivery modes are likely to continue, and 
students of all ages can use them. Future online education will be less limited by single-teaching-style traditions, as educators will be able to support pedagogical approaches from a menu of instructional delivery options, a combination that previous generations of online educators have adopted [15].

It's also crucial to change how learning outcomes are assessed in online environments. Many educators have altered the way they assess student success, eliminating assignments and fully changing assessment methods [16]. Changes in learning can be made using strategies that take advantage of the online delivery mode, such as collaborative conversations, student-led teaching, and the use of games to increase motivation and concentration [17]. More authentic experiences that involve the practical application of newly acquired skills and expertise, such as team-based projects incorporating many innovative and social media platforms in support of collaborative problem solving, are all likely to continue [18-20].

Empirical research is conducted in this paper to examine students' perceptions of the efficacy of technology-assisted online education during the COVID-19 pandemic. Data obtained from students through an online survey is used to assess their perceptions. Data is obtained in a specific manner, then cleansed, normalized, and replicated following the requirements. Tables and graphs were used to analyze and interpret the data. The chi-square statistical model was used to test the hypotheses. Finally, the findings were listed, along with a few suggestions.

\section{REVIEW OF LITERATURE :}

This study began with the review of literature related to the analysis of online surveys using different statistical techniques. Mukhtar et al. (2020) [21] analyzed the effectiveness of online classes using the maximum variation sampling technique. This analysis was carried out to explore the perception of both medical students and their teachers regarding online classes that were conducted during the outbreak of the COVID-19 pandemic. Both learners and teachers opined that online learning is more flexible and effective especially when the convention mode of teaching-learning is impossible. The ubiquitous access to the digital learning material, suppleness of online learning made students self-directed and self-motivated learners. However, in their opinion, in online learning, there is very limited exposure to practical subjects.

Szpringer \& Monika (2020) [22] found that before the pandemic situation e-learning was not that popular because of the need for reliable internet sources and the essential hardware and software requirements. To make online learning more effective interactive techniques are to be used. Selflearning abilities of the students, abundantly available learning material, the guidance of teacher/instructor, and ease of use of technology have play important role in the effectiveness of online education.

Variables required for the analysis were identified using confirmatory factor analysis. according to students' opinion, there is more scope and freedom to connect with the teachers during e-learning with the aid of technology. Self-efficacy of students, ease of access to the digital learning material, ease of use of technology) are considered as the driving forces in the success of online learning during the pandemic (Chen et al., 2020 [23]. User satisfaction can be measured to improve the result of any product or service. Online surveys play a crucial role in achieving the same. Once the data is collected, it can be analyzed using statistical techniques and models. During the current situation of the pandemic, it is essential to consider the impact of public health emergencies when developing a model for analysis (Doyumğaç et al., 2021) [24].

Muthuprasad et al. (2021) [25] found that to strengthen the effectiveness of online education learner's feedback is considered as the essential aspect to be analyzed to evaluate the effectiveness of online classes. The instructor's ability to manage the class, interact with students, make students involved in the classes and familiarity with the technology are identified as favorable factors of online education. However, the absence of face-to-face interaction, minimum collaboration with seniors and peers, lack of practical exposure act as hindrances to the success of online education.

Higher level of concentration, adaptiveness, and self-discipline the essential attributes for students when pursuing education via online mode. The methodology adopted by the institution, instructor's skills to make class more interactive increase the effectiveness of online classes. However, they cannot be treated as an alternative to the conventional mode of teaching-learning (Naik et al., 2021) [26]. To understand the effectiveness of online classes major hurdles are to be understood and analyzed effectively. The facilitators and the policymakers of online education should identify the barriers and 
investigate thoroughly (Ming et al., 2021) [27]. Less familiarity with the technology, poor internet connectivity, poor technical support, etc. are the major problems faced by teachers when engaging in online classes (Bakhmat et al., 2021) [28]. Online education is practiced just to impart education uninterruptedly during the outbreak of the COVID-19 pandemic. Students exhibited little dissatisfaction but a majority of them did not exhibit any symptoms of depression (Fawaz \& Muna, 2021) [29]. In most of the universities and intuitions of higher education, online education was a part of their curriculum. The COVID-19 pandemic has brought a rapid change to conventional teaching-learning. There was no other go for all the educational institutions. For the smooth functioning of the teaching-learning process, there was no other go for educational institutions except to embrace online education (Fawaz \& Muna, 2021) [30]. The summary of related work is given in Table-1.

Table 1: Summary of related work

\begin{tabular}{|c|c|c|c|}
\hline $\mathbf{S N}$ & Authors & Year & Methodology/Findings \\
\hline 1 & $\begin{array}{l}\text { Mukhtar et al. } \\
\text { [21] }\end{array}$ & 2020 & $\begin{array}{l}\text { Used maximum variation sampling technique to analyze the } \\
\text { effectiveness of online classes from the perspective of medical } \\
\text { students and their teachers. The study revealed that students have } \\
\text { become self-motivated learners by accessing abundant digital } \\
\text { learning resources. }\end{array}$ \\
\hline 2 & $\begin{array}{l}\text { Szpringer \& } \\
\text { Monika [22 ] }\end{array}$ & 2020 & $\begin{array}{l}\text { Applied Chi-square method to measure the level of acceptance of e- } \\
\text { learning. The finding is e-learning has become a popular tool because } \\
\text { of the pandemic. }\end{array}$ \\
\hline 3 & Chen et al. [23] & 2020 & $\begin{array}{l}\text { Developed a model based on a neural network that uses satisfaction } \\
\text { index and concluded that the personal factors related to users do not } \\
\text { directly affect their satisfaction with online classes whereas the } \\
\text { availability of resources and familiarity with the technology has a } \\
\text { greater impact. }\end{array}$ \\
\hline 4 & $\begin{array}{l}\text { Doyumğaç et al. } \\
\text { [24] }\end{array}$ & 2021 & $\begin{array}{l}\text { Used Cronbach's alpha technique and confirmatory factor analysis } \\
\text { for investigating the effectiveness of online education from the } \\
\text { perspective of students. The data were tested using AMOS software } \\
\text { and found that students have inclined towards online education } \\
\text { during the pandemic because of acceptance and usefulness of } \\
\text { technology. }\end{array}$ \\
\hline 5 & $\begin{array}{l}\text { thuprasad et } \\
\text { [25] }\end{array}$ & 2021 & $\begin{array}{l}\text { Used Friedman's test and Castle and Weiman formula to calculate } \\
\text { the rank and consensus related to students' satisfaction and found that } \\
\text { majority of students confirmed an optimistic attitude towards online } \\
\text { education specifically during the period of the pandemic as a means } \\
\text { of continuity. }\end{array}$ \\
\hline 6 & Naik et al. [26] & 2021 & $\begin{array}{l}\text { Conducted a virtual survey and concluded that students get less } \\
\text { practical exposure, less interaction become a hindrance to the success } \\
\text { of online education which requires self-disciplined and self- } \\
\text { motivated students }\end{array}$ \\
\hline 7 & al. [27] & 2021 & $\begin{array}{l}\text { The online photovoltaic model was used to gather information from } \\
\text { different categories of students and get meaningful information on } \\
\text { students' satisfaction with online classes. The study concludes that } \\
\text { when the conventional method of teaching-learning is not possible, } \\
\text { live sessions where there is some sort of interaction are to be } \\
\text { conducted. }\end{array}$ \\
\hline 8 & $\begin{array}{l}\text { Bakhmat et al. } \\
\text { [28] }\end{array}$ & 2021 & $\begin{array}{l}\text { Conducted online survey to uncover the difficulties, and advantages } \\
\text { of online classes from the perspective of teachers of higher education. } \\
\text { The survey revealed that the teachers have mixed opinions as far as } \\
\text { online classes are concerned. }\end{array}$ \\
\hline 9 & $\begin{array}{l}\text { Fawaz \& Muna } \\
\text { [29] }\end{array}$ & 2021 & $\begin{array}{l}\text { A survey was conducted to analyze the mental health of the students } \\
\text { pursuing their education in online mode during the outbreak of the } \\
\text { pandemic COVID-19. The analysis was carried out using the Chi- } \\
\text { Square method and a majority of students did not show any sign of } \\
\text { depression or anxiety. }\end{array}$ \\
\hline
\end{tabular}




\begin{tabular}{|l|l|l|l|}
\hline 10 & Ds et al. [30] & 2021 & $\begin{array}{l}\text { The discover, learn, practice, collaborate and access (DLPCA) was } \\
\text { used to make online classes more effective and interactive. } \\
\text { Synchronous learning technique is found as more effective and } \\
\text { interactive when pursuing education through online classes. }\end{array}$ \\
\hline
\end{tabular}

Following a review of the existing published research works of various scholars, it was found that no significant work has been done to assess the perceptions of undergraduate and post graduate students on the efficacy of online education. As technology advances and new ways and possibilities become accessible, students' perception on online education may shift throughout time. There is lack of sufficient research done to analyze the feedback of the students on online education in this coastal region of Karnataka \& Kerala. This was identified as a gap by the researchers, prompting them to conduct the current study.

\section{OBJECTIVES :}

- To investigate students' perceptions of the effectiveness of technology-assisted online education during the COVID-19 Pandemic.

- To learn how, in the face of the COVID-19 Pandemic, technology-assisted online education is the ideal alternative to conventional classroom-based education.

- To determine whether students receive the same amount of learning from online education as they do from traditional education.

- To see if there is a gender gap in terms of online education satisfaction.

\section{HYPOTHESIS :}

1. $\mathrm{H}_{1}$ : Technology-assisted online education is the perfect alternative to traditional classroombased education in this COVID-19 Pandemic situation.

2. $\mathrm{H}_{2}$ : Both male and female students are equally satisfied with online education.

3. $\mathrm{H}_{3}$ : Students were not stressed while learning remotely during the COVID-19 pandemic.

4. $\mathrm{H}_{4}$ : Students believe they gain enough theoretical and practical experience from online education.

\section{SCOPE AND LIMITATION OF THE STUDY :}

This empirical research aims to see whether students in higher educational institutions are satisfied with technology-assisted Online Education during the COVID-19 pandemic. The study used data collected through an online survey to learn how students are dealing with online education, which has been around for a long time but is still underutilized, and how satisfied they are with it. During April 2021, data was obtained. The online survey form was kept open for a week to allow respondents to reply. The participating population does not have a regional boundary. However, the majority of the respondents are from the states of Karnataka and Kerala. The study aimed to find answers to the following research questions:

- Is online education a viable substitute for conventional classroom instruction?

- Is there parity between different types of educational institutions when it comes to coordinating online learning?

- Is there a gender gap in terms of online education acceptance?

- Is there any way that online education has helped students improve their learning experience? As with the majority of studies, the design of the current study is subject to limitations. They are: the respondents are not restricted by geography, the survey did not target a particular demographic, because of their cultural backgrounds or viewpoints on such phenomena, respondents' opinions may be skewed and respondents were given a very short amount of time to record their opinions.

\section{METHODOLOGY :}

Students' satisfaction with technology-assisted online education at higher education institutions was investigated via an exploratory research analysis using a virtual survey. The non-probability sampling technique convenience sampling was used to collect data for the analysis. The aim of using these methods is to come up with hypotheses and conduct exploratory research on the topic. It also addresses budget and time constraints. As participants in this research, students from higher education institutions 
responded to the survey. Higher education students are preferred because they have already been exposed to technology, online platforms, and the ability to adapt, which is the essence of remote learning. The sample size needed for this study was calculated using an online service provided by Statistics Kingdom (https://www. statskingdom.com/50_ci_sample_size.html). To achieve the required confidence interval, the sample size is calculated as Confidence level: 0.95 (95\%), a margin of error: 0.05 . The standard deviation is based on the proportion is: $\sqrt{ }(p(1-p))=0.50$. Calculates the sample size to get the following confidence interval: $0.5 \pm 0.05 . \alpha=1-0.95=0.050 . \mathrm{Z}_{(1-\alpha / 2)}=\mathrm{Z}_{(1-0.050 / 2)}=\mathrm{Z} 0.975=$ 1.96. The required sample size is: $\mathrm{n}=\mathrm{Z}^{2} 0.975 * \mathrm{p}(1-\mathrm{p}) / \mathrm{MOE}^{2}=1.96^{2 *} 0.5(1-0.5) / 0.05^{2}=385$, rounded up from: 384.15 .

A convenience sampling technique was used to select research subjects and the final study sample consisted of 1241 subjects who replied to the questionnaire. Using Google Forms (https://forms.gle/ HcyELW1fQjBq1QLM8), a self-designed questionnaire in the English language was developed specifically for the study. To double-check the quality of the questionnaire, a senior professor in the field of economics was consulted. First to final year degree and postgraduate students in colleges were included in the survey. The Google Form's URL was distributed via social media platforms such as email and WhatsApp. The participants were given one week time to record their responses [31-35].

The objective type survey was divided into four categories - about the respondent, technology-assisted online education, students' knowledge, and experience, and to evaluate students' exposure to online education. The purpose of the study was explained to the participants in the instructions part. Respondents were required to fill out demographic and academic information after clicking the link. The first section of the survey asks about the types of technology that students use and their experiences with it. The second section inquiries about technology-assisted online education. The third section asked about the students' knowledge gained and experience acquired through online education. The final section includes questions that measure students' exposure to online education technology and applications.

Counts and percentages, as well as online resources, were used to perform the descriptive statistical analysis. Data were analyzed in an exploratory way. Tables and graphs were used to interpret the data that had been analyzed. Hypotheses were then tested using the chi-square test model. Finally, some recommendations and suggestions were made based on the analysis.

\section{DATA ANALYSIS AND INTERPRETATION :}

Table- 2 shows the personal profiles of the respondents. Male students account for $58 \%$ of the 1241 respondents, while female students account for $42 \%$. Undergraduate students made up $82 \%$ of respondents, while postgraduate students made up $18 \%$. There are $66 \%$ of respondents who attend institutions in urban areas, $22 \%$ in suburban areas, and $12 \%$ in rural areas. Just $2 \%$ of respondents said Kannada is their medium of instruction, while $98 \%$ said English is theirs. The majority of respondents, $78 \%$, are studying in private institutions. $17 \%$ of respondents are studying in Aided institutions, $4 \% \mathrm{n}$ Government, and $1 \%$ in Sponsored institutions.

Table 2: Personal Profile of the Respondents

\begin{tabular}{|l|l|r|r|}
\hline \multicolumn{1}{|c|}{ Variable } & \multicolumn{1}{|c|}{ Options } & Frequency & Percentage \\
\hline \multirow{4}{*}{ Gender } & Male & 516 & 42 \\
\cline { 2 - 4 } & Female & 725 & 58 \\
\cline { 2 - 4 } & Total & 1241 & 100 \\
\hline \multirow{4}{*}{ Education Level } & UG & 1018 & 82 \\
\cline { 2 - 4 } & PG & 223 & 18 \\
\cline { 2 - 4 } & Total & 1241 & 100 \\
\hline \multirow{4}{*}{$\begin{array}{l}\text { Medium of } \\
\text { Instruction }\end{array}$} & Rural & 273 & 22 \\
\cline { 2 - 4 } & Suburban & 146 & 12 \\
\cline { 2 - 4 } & Urban & 822 & 66 \\
\cline { 2 - 4 } & Total & 1241 & 100 \\
\hline
\end{tabular}




\begin{tabular}{|l|l|r|r|}
\hline & Total & 1241 & 100 \\
\hline \multirow{4}{*}{ Institution Type } & Aided & 210 & 17 \\
\cline { 2 - 4 } & Government & 50 & 4 \\
\cline { 2 - 4 } & Private & 966 & 78 \\
\cline { 2 - 4 } & Sponsored & 15 & 1 \\
\cline { 2 - 4 } & Total & 1241 & 100 \\
\hline
\end{tabular}

Because online education is delivered by teachers from remote locations, students need gadgets to access it. Gadgets include personal computers, laptops, hand-held devices such as smartphones \& tablets, and smart TVs. Smartphones are one of the most economical and reasonable options for students. The survey indicates, students prominently use (87\%) smart devices to attend online classes. $85 \%$ of students use their smartphones to access online classes, while $12 \%$ use their laptops. Only $3 \%$ of students use personal computers $(0.64 \%)$, tablets $(0.64 \%)$, smart TVs $(0.81 \%)$, and other devices $(1.13 \%)$ to access online classes. Figure-1 below clearly indicating the devices prominently used by students for attending online classes

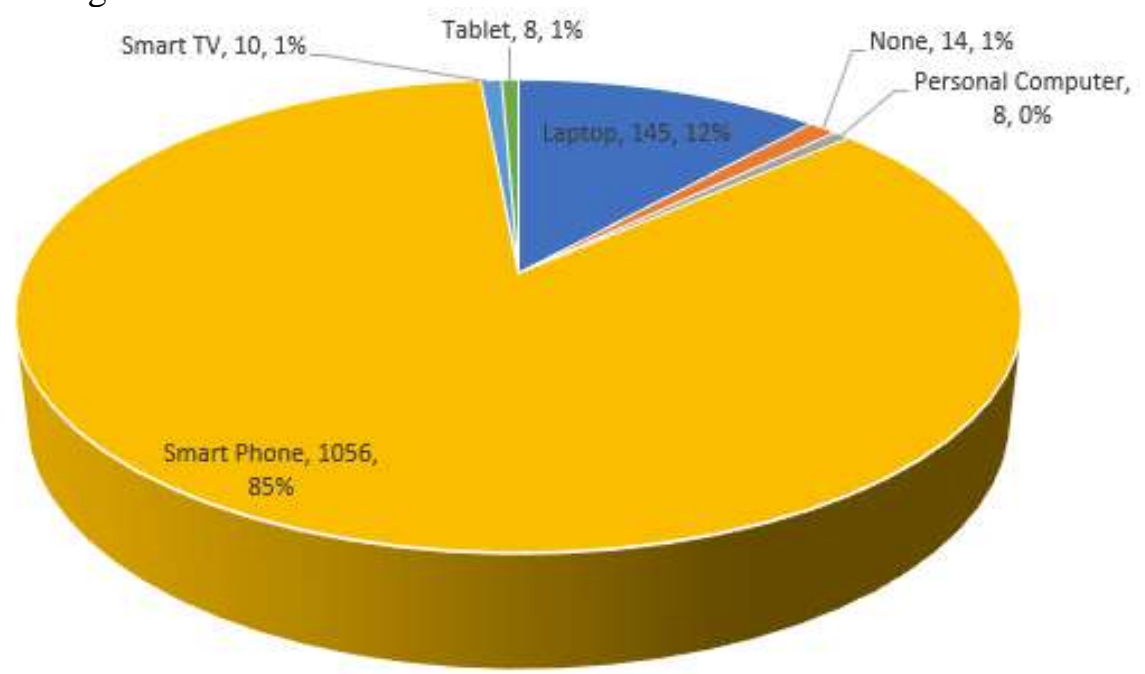

Fig. 1: Device prominently used by students for attending online classes

Students are self-reliant in terms of the devices they use to take online classes. Only $1 \%$ of students make use of the devices offered by the institution. Figure 2 below showing the reliance on devices used for online classes by students. The majority of students (85\%) find it easy to attend online classes because they are using their own devices or share devices with their peers. However, because they share devices with their families, a few students (14\%) are having difficulty keeping up with their online class schedules.

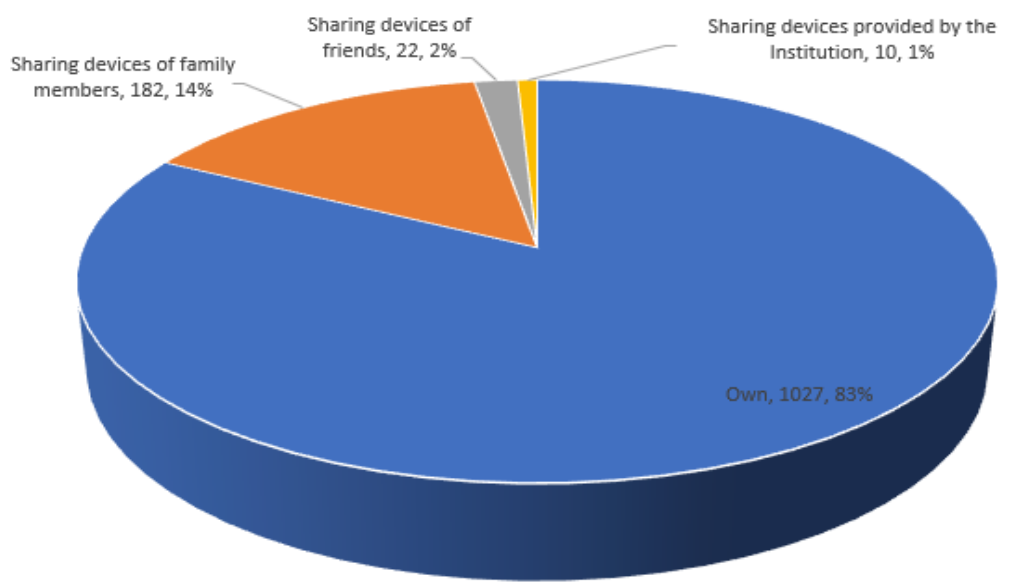

Fig. 2: Reliance on devices used for online classes by students

Online education includes both online instruction and online student evaluation. Teachers' responsibilities will extend beyond simply giving lectures online; they will need to assess how well 
students absorbed topics, how well they deal with instructional methods, and whether or not students are meeting the required learning goals, among other things. Conducting online tests, examinations, quizzes, and other forms of assessment is one way to assess students' progress. In this survey respondents opine that writing exams offline and uploading scanned response scripts (46\%) and online quizzes (31\%) are the most common ways for teachers to evaluate student's performance online. Only $11 \%$ of students opined they were assessed using dedicated online exam software. To ensure the sanctity of the examination, about $9 \%$ of teachers conduct - write the exam in front of a live camera and then upload the scanned responses method. About $7 \%$ of teachers use open book exams to assess their pupils' progress.

Students' perceptions of any style of education delivery are important in determining its effectiveness and continuing with it. If they are satisfied, keep doing so; if not, the educator must use appropriate adaptable approaches to make it acceptable to them. Table-3 below clearly showing students' perception of online education. $75 \%$ of survey respondents are satisfied with online education, whereas twentyfive percent are either uninterested or dissatisfied. Male students (40\%) make up the majority of the $25 \%$ that are uninterested or unsatisfied and female students are just $16 \%$. In other words, $84 \%$ of female students view online education to be the most convenient, compared to only $60 \%$ of male students. $2.18 \%$ of students believe that online education is an excellent option to traditional education. Online education is viewed as a good alternative to traditional education by $34.62 \%$ of female students and $20.54 \%$ of male students. In comparison to classroom-based education, online education is regarded as an average alternative by $46.62 \%$ of female students and $39.53 \%$ of male students.

Table 3: Students perception towards online education

\begin{tabular}{|l|r|r|r|r|r|r|}
\hline Options & \multicolumn{2}{|c|}{ Female } & \multicolumn{2}{c|}{ Male } & \multicolumn{2}{c|}{ Total } \\
\hline & Frequency & Percentage & Frequency & Percentage & Frequency & Percentage \\
\hline Excellent & 17 & 2.34 & 10 & 1.94 & 27 & 2.18 \\
\hline Good & 251 & 34.62 & 106 & 20.54 & 357 & 28.77 \\
\hline Average & 338 & 46.62 & 204 & 39.53 & 542 & 43.67 \\
\hline Not interesting & 76 & 10.48 & 94 & 18.22 & 170 & 13.7 \\
\hline Poor & 43 & 5.93 & 102 & 19.77 & 145 & 11.68 \\
\hline
\end{tabular}

Online education can be delivered in several ways. The two main methods are synchronous and asynchronous. The one way to accomplish online education is to conduct it in real-time. Another option is to capture class videos and upload them to video streaming sites, where students can access them. According to the survey, $90 \%$ of online class activities take place in the form of live or video classes. In private institutions, it is $90.89 \%, 86.19 \%$ in aided institutions, $98 \%$ in government institutions, and $90.41 \%$ in sponsored institutions. Video lessons are the most popular method of teaching in online education. More than half of all teaching activities take place in this mode. Teachers and students prefer video classes since they do not need to be online all of the time to participate in deliberations, which requires a high-speed and steady internet connection, furthermore, teachers and students will be able to share their devices with family members and peers. Table- 4 below is highlighting how online classes delivered to students.

Table 4: How are online classes delivered to students?

\begin{tabular}{|l|r|r|r|r|r|r|r|r|r|r|}
\hline Options & \multicolumn{2}{|c|}{ Aided } & \multicolumn{2}{|c|}{ Government } & \multicolumn{2}{c|}{ Private } & \multicolumn{2}{c|}{ Sponsored } & \multicolumn{2}{|c|}{ Total } \\
\hline & Freq & \multicolumn{1}{|c|}{$\%$} & Freq & $\%$ & Freq & $\%$ & Freq & $\%$ & Freq & $\%$ \\
\hline $\begin{array}{l}\text { Just sharing learning } \\
\text { materials }\end{array}$ & 29 & 13.81 & 1 & 2 & 88 & 9.11 & 1 & 6.67 & 119 & 9.59 \\
\hline Live & 24 & 11.43 & 16 & 32 & 213 & 22.05 & 6 & 40 & 259 & 20.87 \\
\hline Live and Video Classes & 37 & 17.62 & 14 & 28 & 241 & 24.95 & 5 & 33.33 & 297 & 23.93 \\
\hline Video Classes & 120 & 57.14 & 19 & 38 & 424 & 43.89 & 3 & 20 & 566 & 45.61 \\
\hline Grand Total & 210 & 100 & 50 & 100 & 966 & 100 & 15 & 100 & 1241 & 100 \\
\hline
\end{tabular}


It is an established reality that students and teachers cannot spend the same amount of time online as they can in a classroom setting due to the lack of resources and technology. Furthermore, constant use of technology and time spent in front of devices causes health problems. The survey states female students spend slightly more time participating in online education activities than male students. Over $91 \%$ of female students spend more than an hour every day on online class-related activities, compared to $86 \%$ of male students. $31 \%$ of students spend less between 1 and 2 hours per day on online class activities, 38\% spend 2-3 hours, 19\% 4-6 hours, and 1\% spend more than 7 hours per day. The most striking statistic is that $11 \%$ of students spend less than 1 hour every day on online learning.

Students must be supplied with study resources in PDF, scanned document, word file, PowerPoint presentations, videos, or other forms as needed to supplement their understanding of the topics covered in online education. Table-5 below displays the frequency at which students receive study materials from teachers during their online education. As per the survey, above $97 \%$ of the respondents view that they receive study materials from teachers during their online education. Teachers almost always distribute study materials shortly after an online lesson (17.16\%). They also provide lesson-by-lesson (35.78\%) or unit-by-unit (22.4\%) study resources when each chapter or unit is completed. Furthermore, based on the requirements (17.16\%), teachers share materials relevant to additional study or to gain additional knowledge.

Table 5: The frequency at which students receive study materials from teachers during online education

\begin{tabular}{|l|r|r|r|r|r|r|r|r|r|r|}
\hline \multirow{2}{*}{ Options } & \multicolumn{2}{|c|}{ Aided } & \multicolumn{2}{c|}{ Government } & \multicolumn{2}{c|}{ Private } & \multicolumn{2}{c|}{ Sponsored } & \multicolumn{2}{c|}{$\begin{array}{c}\text { Grand } \\
\text { Total }\end{array}$} \\
\cline { 2 - 12 } & Freq & \multicolumn{1}{c|}{$\%$} & Freq & \multicolumn{1}{c|}{ Freq } & $\%$ & Freq & $\%$ & Freq & $\%$ \\
\hline $\begin{array}{l}\text { Based on the } \\
\text { requirement }\end{array}$ & 31 & 14.29 & 7 & 14 & 167 & 17.29 & 5 & 33.33 & 213 & 17.16 \\
\hline Soon after the class & 95 & 43.78 & 21 & 42 & 324 & 33.54 & 4 & 26.67 & 444 & 35.78 \\
\hline Lesson-wise & 32 & 14.75 & 5 & 10 & 176 & 18.22 & 4 & 26.67 & 215 & 17.32 \\
\hline Weekly once & 19 & 8.76 & 6 & 12 & 34 & 3.52 & 1 & 6.67 & 59 & 4.75 \\
\hline Unit-wise & 30 & 13.82 & 10 & 20 & 237 & 24.53 & 1 & 6.67 & 278 & 22.4 \\
\hline Not receiving & 3 & 1.38 & 1 & 2 & 28 & 2.9 & 0 & 0 & 32 & 2.58 \\
\hline
\end{tabular}

The effectiveness of online education has been acknowledged by students. They believe that while online education is not a substitute for traditional classroom-based education, it may be beneficial if offered with the right technology and methodologies. Only 19\% of the respondents believe that online education is ineffective. Furthermore, when compared to their undergraduate counterparts (16\%), postgraduate students $(25.56 \%)$ are more dissatisfied with the efficacy of online education. The remaining $81 \%$ of respondents are fully satisfied or rather satisfied with the effectiveness of online education delivery. Online education is viewed as very effective by $9 \%$ of respondents. According to $21 \%$ of respondents, online education is moderately effective, and on average, according to $52 \%$. In comparison to their rural counterparts, urban and suburban students believe that internet-based education is more or rather effective. The reason for this is that students in cities and suburbs can acquire education via the internet without encountering any technical difficulties or network issues. However, access to technology and the internet is the greatest difficulty for rural pupils. The summary of the significance of online education in the views of students is given in Table-6 below.

Table 6: The significance of online education in the views of students

\begin{tabular}{|r|r|r|r|r|r|r|}
\hline \multirow{2}{*}{ Options } & \multicolumn{2}{|c|}{ Degree } & \multicolumn{2}{c|}{ Post-Graduation } & \multicolumn{2}{c|}{ Grand Total } \\
\cline { 2 - 7 } & \multicolumn{1}{|c|}{ Freq } & \multicolumn{1}{c|}{$\%$} & \multicolumn{1}{c|}{ Freq } & \multicolumn{1}{c|}{$\%$} & \multicolumn{1}{c|}{ Freq } & \multicolumn{1}{c|}{$\%$} \\
\hline Extremely Effective & $\mathbf{1 4}$ & $\mathbf{1 . 3 8}$ & $\mathbf{1 1}$ & $\mathbf{4 . 9 3}$ & $\mathbf{2 5}$ & $\mathbf{2 . 0 1}$ \\
\hline Female & 8 & 57.14 & 6 & 54.55 & 14 & 56 \\
\hline Male & 6 & 42.86 & 5 & 45.45 & 11 & 44 \\
\hline Very Effective & $\mathbf{8 5}$ & $\mathbf{8 . 3 5}$ & $\mathbf{1 0}$ & $\mathbf{4 . 4 8}$ & $\mathbf{9 5}$ & $\mathbf{7 . 6 6}$ \\
\hline Female & 51 & 60 & 7 & 70 & 58 & 61.05 \\
\hline
\end{tabular}




\begin{tabular}{|r|r|r|r|r|r|r|}
\hline Male & 34 & 40 & 3 & 30 & 37 & 38.95 \\
\hline Partially Effective & $\mathbf{2 0 5}$ & $\mathbf{2 0 . 1 4}$ & $\mathbf{5 1}$ & $\mathbf{2 2 . 8 7}$ & $\mathbf{2 5 9}$ & $\mathbf{2 0 . 8 7}$ \\
\hline Female & 107 & 52.2 & 36 & 70.59 & 145 & 55.98 \\
\hline Male & 98 & 47.8 & 15 & 29.41 & 114 & 44.02 \\
\hline Average & $\mathbf{5 4 1}$ & $\mathbf{5 3 . 1 4}$ & $\mathbf{9 4}$ & $\mathbf{4 2 . 1 5}$ & $\mathbf{6 4 1}$ & $\mathbf{5 1 . 6 5}$ \\
\hline Female & 346 & 63.96 & 74 & 78.72 & 424 & 66.15 \\
\hline Male & 195 & 36.04 & 20 & 21.28 & 217 & 33.85 \\
\hline Not at all Effective & $\mathbf{1 7 3}$ & $\mathbf{1 6 . 9 9}$ & $\mathbf{5 7}$ & $\mathbf{2 5 . 5 6}$ & $\mathbf{2 3 2}$ & $\mathbf{1 8 . 6 9}$ \\
\hline Female & 57 & 32.95 & 33 & 57.89 & 90 & 38.79 \\
\hline Male & 116 & 67.05 & 24 & 42.11 & 142 & 61.21 \\
\hline
\end{tabular}

Students have conflicting feelings about the impact of online learning on their learning experience. While half of the students believe that online education has aided them in gaining knowledge while also providing a better learning experience, an equal proportion of students disagree. It has benefited them in some way, according to $49 \%$ of female students and $37 \%$ of male students. Perspectives of students on the effect of online learning on their learning experience are represented in Figure-3 below.

Perspectives of female students on the effect of online learning on their learning experience

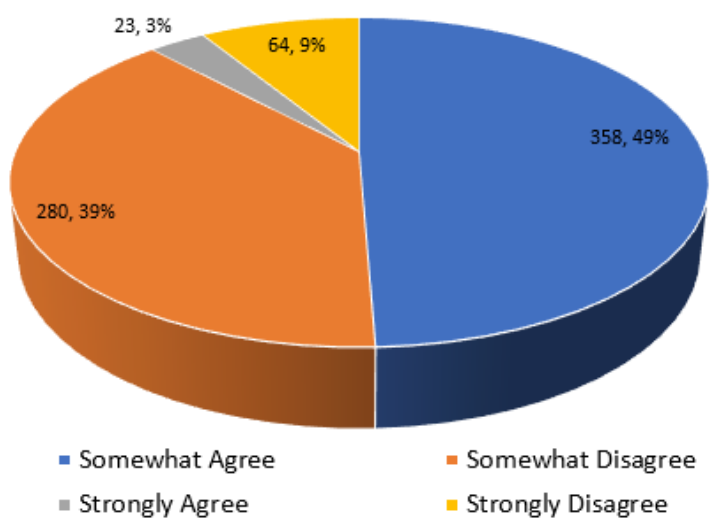

Perspectives of male students on the effect of online learning on their learning experience

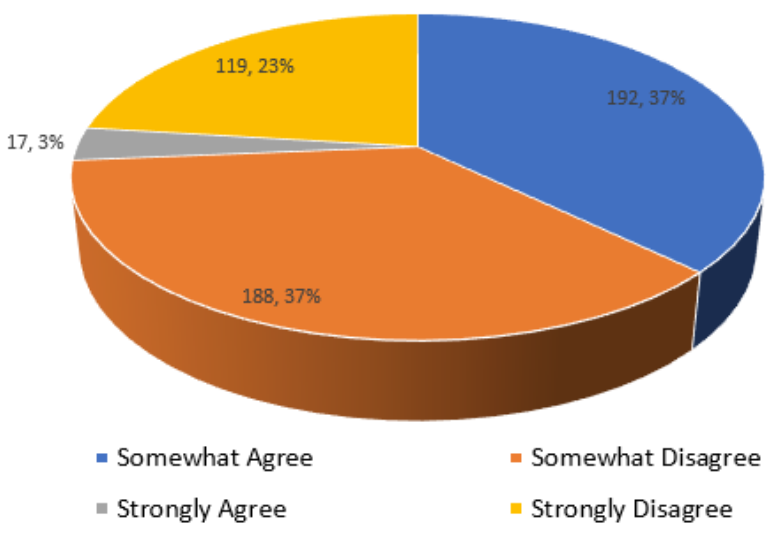

Fig. 3: Perspectives of students on the effect of online learning on their learning experience

The effectiveness of online education is dependent on how well technology and software tools are used to provide it. Students can cope better with education rather than technological obstacles if open and free software tools and user-friendly technologies are used by the teachers. As per the survey, students are not fully satisfied with the technologies and applications that teachers employ for online education delivery. Only $30 \%$ of female students and $20 \%$ of male students are fully satisfied with how their teachers use technology to conduct online classes. Approximately $63 \%$ of respondents are satisfied to some extent. $6 \%$ of female students and $16 \%$ of male students are dissatisfied with their teachers' use of technology in online education. Table-7 below summarizing students' satisfaction with the technologies and software that teachers use for online education.

Table 7: Students' satisfaction with the technologies and software that teachers use for online education

\begin{tabular}{|r|r|r|r|r|r|r|}
\hline \multicolumn{1}{|c|}{ Options } & Degree & \multicolumn{1}{c|}{$\%$} & \multicolumn{1}{c|}{ PG } & \multicolumn{1}{c|}{$\%$} & \multicolumn{1}{c|}{ Total } & \multicolumn{1}{c|}{$\%$} \\
\hline Female & 569 & 55.89 & 156 & 69.96 & 725 & 58.42 \\
\hline Extremely satisfied & 27 & 4.75 & 2 & 1.28 & 29 & 4 \\
\hline Very satisfied & 159 & 27.94 & 33 & 21.15 & 192 & 26.48 \\
\hline Moderately satisfied & 214 & 37.61 & 67 & 42.95 & 281 & 38.76 \\
\hline Slightly satisfied & 137 & 24.08 & 41 & 26.28 & 178 & 24.55 \\
\hline Not at all satisfied & 32 & 5.62 & 13 & 8.33 & 45 & 6.21 \\
\hline Male & 449 & 44.11 & 67 & 30.04 & 516 & 41.58 \\
\hline Extremely satisfied & 27 & 6.01 & 0 & 0 & 27 & 5.23 \\
\hline
\end{tabular}




\begin{tabular}{|r|r|r|r|r|r|r|}
\hline Very satisfied & 68 & 15.14 & 12 & 17.91 & 80 & 15.5 \\
\hline Moderately satisfied & 180 & 40.09 & 27 & 40.3 & 207 & 40.12 \\
\hline Slightly satisfied & 100 & 22.27 & 17 & 25.37 & 117 & 22.67 \\
\hline Not at all satisfied & 74 & 16.48 & 11 & 16.42 & 85 & 16.47 \\
\hline
\end{tabular}

When the teacher and students engage face to face, the teaching-learning process becomes more successful. This is a common aspect of classroom-based education, and it is possible to create a similar environment in an online setting. Teaching-learning is dynamic and progressive when teachers and students communicate face-to-face. This survey response backs it up. Table- 8 below clearly indicating students' feedback on the importance of face-to-face communication while learning remotely. More than $90 \%$ of the respondents believe that face-to-face communication is vital when learning online. Face-to-face communication is very important to $48 \%$ of respondents, and $42 \%$ believe it is helpful in some manner. Only about $10 \%$ of students think it is irrelevant.

Table 8: Students feedback on the importance of face-to-face communication while learning remotely

\begin{tabular}{|l|r|r|r|r|r|r|}
\hline Options & \multicolumn{1}{c|}{ Degree } & \multicolumn{1}{c|}{$\%$} & \multicolumn{1}{c|}{ PG } & \multicolumn{1}{c|}{$\%$} & \multicolumn{1}{c|}{ Total } & \multicolumn{1}{c|}{$\%$} \\
\hline Extremely important & 169 & 16.6 & 32 & 14.35 & 201 & 16.2 \\
\hline Very important & 310 & 30.45 & 85 & 38.12 & 395 & 31.83 \\
\hline Moderately important & 277 & 27.21 & 62 & 27.8 & 339 & 27.32 \\
\hline Slightly important & 162 & 15.91 & 26 & 11.66 & 188 & 15.15 \\
\hline Not at all important & 100 & 9.82 & 18 & 8.07 & 118 & 9.51 \\
\hline
\end{tabular}

Students feel isolated from peers, teachers, extended families, and community networks when they learn online. Peer relations and a sense of belonging are crucial aspects that students are missing out on. Students learn just as much from their peers and their surroundings as from their teachers. The in-person contacts they create with their peers at lunch breaks, on the playground, or after school are an important component of their development. Shifting education to an online environment will not be able to replace this entire educational experience. Table-9 below showing students' feedback on how stressful they while learning remotely during the COVID-19 pandemic. According to this survey, $90 \%$ of students feeling stressed when taking online classes and only $10 \%$ of students say they are not at all stressed. 36 $\%$ of students believe they are more stressful and $64 \%$ say somewhat stressful.

Table 9: Students feedback on how stressful they while learning remotely during the COVID-19 pandemic

\begin{tabular}{|c|c|c|c|c|c|c|}
\hline Options & Female & $\%$ & Male & $\%$ & Total & $\%$ \\
\hline Extremely stressful & 49 & 6.76 & 67 & 12.98 & 116 & 9.35 \\
\hline Degree & 29 & 59.18 & 57 & 85.07 & 86 & 74.14 \\
\hline Post-Graduation & 20 & 40.82 & 10 & 14.93 & 30 & 25.86 \\
\hline Very stressful & 112 & 15.45 & 95 & 18.41 & 207 & 16.68 \\
\hline Degree & 84 & 75 & 79 & 83.16 & 163 & 78.74 \\
\hline Post-Graduation & 28 & 25 & 16 & 16.84 & 44 & 21.26 \\
\hline Moderately stressful & 232 & 32 & 146 & 28.29 & 378 & 30.46 \\
\hline Degree & 191 & 82.33 & 125 & 85.62 & 316 & 83.6 \\
\hline Post-Graduation & 41 & 17.67 & 21 & 14.38 & 60 & 15.87 \\
\hline Slightly stressful & 256 & 35.31 & 156 & 30.23 & 412 & 33.2 \\
\hline Degree & 198 & 77.34 & 140 & 89.74 & 338 & 82.04 \\
\hline Post-Graduation & 58 & 22.66 & 16 & 10.26 & 74 & 17.96 \\
\hline Not at all stressful & 76 & 10.48 & 52 & 10.08 & 128 & 10.31 \\
\hline Degree & 67 & 88.16 & 48 & 92.31 & 115 & 89.84 \\
\hline Post-Graduation & 9 & 11.84 & 4 & 7.69 & 13 & 10.16 \\
\hline
\end{tabular}


Teachers and students in online education are obliged to work from remote locations, most often their homes. They tend to assist themselves in gaining the essential resources and technologies when they are at home and participating in online education. They must also create an environment conducive to the smooth conduct of academic activities. All of this necessitates the assistance of parents. According to the students. parents are supportive of their children's online education. In Table-10 below students' thoughts on their parents' support for online learning are highlighted. Approximately $94 \%$ of respondents believe that their parents are supportive of their wards' online education. Among them, $43 \%$ believe their parents are extremely helpful in all aspects, and $51 \%$ believe their parents support them in some way. Only $6 \%$ of respondents believe they received no assistance from their parents for remote education during the pandemic.

Table 10: Students' thoughts on their parents' support for online learning

\begin{tabular}{|c|c|c|c|c|c|c|}
\hline Options & Female & $\%$ & Male & $\%$ & Total & $\%$ \\
\hline Extremely helpful & 126 & 17.38 & 62 & 12.02 & 188 & 15.15 \\
\hline Rural & 24 & 19.05 & 11 & 17.74 & 35 & 18.62 \\
\hline Suburban & 14 & 11.11 & 13 & 20.97 & 27 & 14.36 \\
\hline Urban & 88 & 69.84 & 38 & 61.29 & 126 & 67.02 \\
\hline Very helpful & 285 & 39.31 & 154 & 29.84 & 439 & 35.37 \\
\hline Rural & 64 & 22.46 & 31 & 20.13 & 95 & 21.64 \\
\hline Suburban & 30 & 10.53 & 20 & 12.99 & 50 & 11.39 \\
\hline Urban & 191 & 67.02 & 103 & 66.88 & 294 & 66.97 \\
\hline Moderately helpful & 151 & 20.83 & 150 & 29.07 & 301 & 24.25 \\
\hline Rural & 23 & 15.23 & 43 & 28.67 & 66 & 21.93 \\
\hline Suburban & 16 & 10.6 & 15 & 10 & 31 & 10.3 \\
\hline Urban & 112 & 74.17 & 92 & 61.33 & 204 & 67.77 \\
\hline Slightly helpful & 135 & 18.62 & 99 & 19.19 & 234 & 18.86 \\
\hline Rural & 32 & 23.7 & 29 & 29.29 & 61 & 26.07 \\
\hline Suburban & 18 & 13.33 & 9 & 9.09 & 27 & 11.54 \\
\hline Urban & 85 & 62.96 & 61 & 61.62 & 146 & 62.39 \\
\hline Not at all helpful & 28 & 3.86 & 51 & 9.88 & 79 & 6.37 \\
\hline Rural & 7 & 25 & 9 & 17.65 & 16 & 20.25 \\
\hline Suburban & 2 & 7.14 & 5 & 9.8 & 7 & 8.86 \\
\hline Urban & 19 & 67.86 & 37 & 72.55 & 56 & 70.89 \\
\hline
\end{tabular}

Students must be more responsible and disciplined in online education because education and learning take place without face-to-face interaction between the students and teachers. Teachers are delivering instruction from distance, without making direct eye contact with students. At the same time, students may take part in online classes as passive learners, active learners, hyperactive learners, or in-absentia learners. As passive learners, they can only hear what the teachers say; as active learners, they can hear the teachers' lessons and make notes on the points; as hyperactive learners, they can hear class, make notes on the points, and interact with teachers via chat and voice; and as in-absentia learners, they simply attend the session, mute audio and video, and work on something unrelated to the session. The survey data reveals about $96 \%$ of the online students are active learners and only $4 \%$ of the students are in-absentia learners. $32 \%$ of students are hyperactive learners who pay attention, take notes, and interact with their teachers. $43 \%$ are active learners who pay attention and take notes. Passive learners account for $21 \%$ of students, who simply listen to the class. Students' method of participation in online classes is given in the Table-11 below. 
Table 11: Students' method of participation in online classes

\begin{tabular}{|c|c|c|c|c|c|c|}
\hline Options & Female & $\%$ & Male & $\%$ & Total & $\%$ \\
\hline Rural & 150 & 20.69 & 123 & 23.84 & 273 & 22 \\
\hline $\begin{array}{r}\text { Listen, note down the important point and } \\
\text { interact with teachers }\end{array}$ & 37 & 24.67 & 48 & 39.02 & 85 & 31.14 \\
\hline Listen and note down the important point & 82 & 54.67 & 39 & 31.71 & 121 & 44.32 \\
\hline Passive listener & 28 & 18.67 & 27 & 21.95 & 55 & 20.15 \\
\hline $\begin{array}{r}\text { Mute the audio and involve in some other } \\
\text { work }\end{array}$ & 3 & 2 & 9 & 7.32 & 12 & 4.4 \\
\hline Suburban & 80 & 11.03 & 62 & 12.02 & 142 & 11.44 \\
\hline $\begin{array}{r}\text { Listen, note down the important point and } \\
\text { interact with teachers }\end{array}$ & 26 & 32.5 & 24 & 38.71 & 50 & 35.21 \\
\hline Listen and note down the important point & 37 & 46.25 & 18 & 29.03 & 55 & 38.73 \\
\hline Passive listener & 15 & 18.75 & 16 & 25.81 & 31 & 21.83 \\
\hline $\begin{array}{r}\text { Mute the audio and involve in some other } \\
\text { work }\end{array}$ & 2 & 2.5 & 4 & 6.45 & 6 & 4.23 \\
\hline Urban & 493 & 68 & 329 & 63.76 & 822 & 66.24 \\
\hline $\begin{array}{r}\text { Listen, note down the important point and } \\
\text { interact with teachers }\end{array}$ & 125 & 25.35 & 132 & 40.12 & 257 & 31.27 \\
\hline Listen and note down the important point & 274 & 55.58 & 120 & 36.47 & 394 & 47.93 \\
\hline Passive listener & 86 & 17.44 & 65 & 19.76 & 151 & 18.37 \\
\hline $\begin{array}{r}\text { Mute the audio and involve in some other } \\
\text { work }\end{array}$ & 10 & 2.03 & 14 & 4.26 & 24 & 2.92 \\
\hline
\end{tabular}

Teachers' responsibilities do not end with class management and curriculum delivery. By taking on the position of moderator, he or she must also encourage students to learn themselves and explore new things. Teachers should extract work from students in the form of assignments, seminars, presentations, and other forms of class works. It is possible to achieve student-centered education this way. Table-12 below presents students' responses on the submission of online classwork. According to the data, $71 \%$ of respondents say they always submit online classwork according to the schedule set by the teachers. $22 \%$ of respondents say they only submit often, while 5\% say they only submit once in a while. Only $2 \%$ of students say they never turn in any of their classwork to their teachers.

Table 12: Students' response on submission of online classwork

\begin{tabular}{|c|c|c|c|c|c|c|}
\hline Options & Female & $\%$ & Male & $\%$ & Total & $\%$ \\
\hline Always & 584 & 80.55 & 291 & 56.4 & 875 & 70.51 \\
\hline Degree & 468 & 80.14 & 243 & 83.51 & 711 & 81.26 \\
\hline Post-Graduation & 116 & 19.86 & 48 & 16.49 & 164 & 18.74 \\
\hline Sometimes & 122 & 16.83 & 154 & 29.84 & 276 & 22.24 \\
\hline Degree & 88 & 72.13 & 142 & 92.21 & 230 & 83.33 \\
\hline Post-Graduation & 34 & 27.87 & 12 & 7.79 & 46 & 16.67 \\
\hline Rarely & 11 & 1.52 & 54 & 10.47 & 65 & 5.24 \\
\hline Degree & 8 & 72.73 & 48 & 88.89 & 56 & 86.15 \\
\hline Post-Graduation & 3 & 27.27 & 6 & 11.11 & 9 & 13.85 \\
\hline Never & 8 & 1.1 & 17 & 3.29 & 25 & 2.01 \\
\hline Degree & 5 & 62.5 & 16 & 94.12 & 21 & 84 \\
\hline Post-Graduation & 3 & 37.5 & 1 & 5.88 & 4 & 16 \\
\hline
\end{tabular}




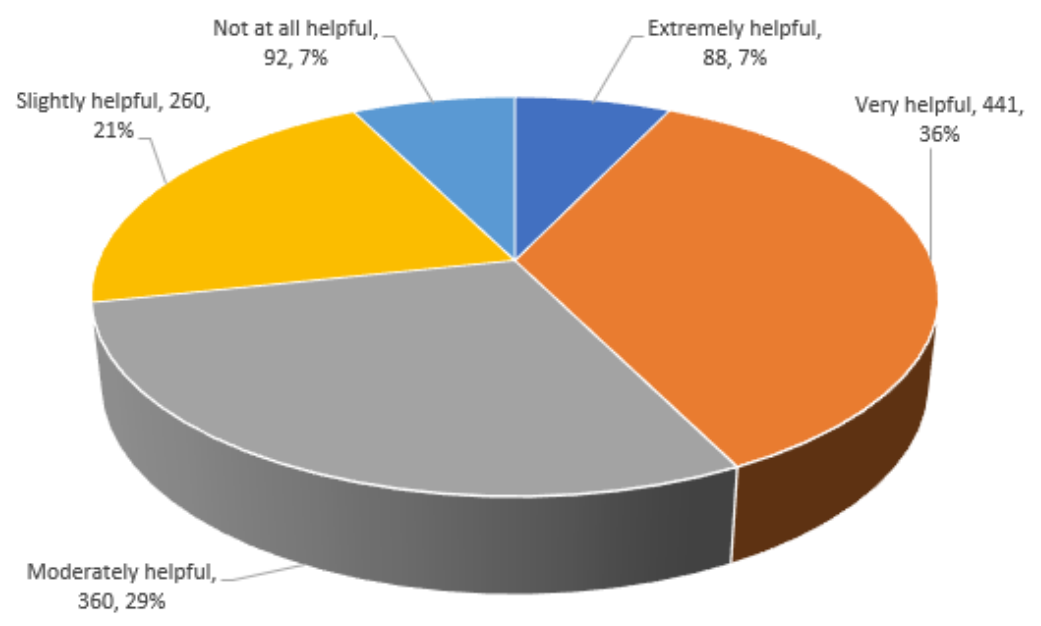

Fig. 4: Students' perspectives on teachers' assistance during online learning

To achieve a conducive academic environment, an online education environment necessitates mutual understanding and cooperation between teachers and students. Even if mutual understanding and cooperation were essential in classroom-based education, the same is expected even more on the online platform because education is delivered in a virtual setting using technology, software, and the internet. Teachers are not simply facilitators of education; they must also be more involved in students' academic activities, as both are on par. Teachers must be available at all times to answer questions, generate ideas, provide timely assistance, and motivate students. Students appreciate how helpful their teachers are during their online education. That is how $93 \%$ of students see it. Teachers are viewed as extremely helpful by $7 \%$ of students, very useful by $36 \%$, somewhat helpful by $29 \%$, and slightly helpful by $21 \%$ of students. Only $7 \%$ of respondents believe their teachers are not helpful in their online education. Students' perspectives on teachers' assistance during online learning are presented in Figure-4 above. Online education is not regarded as a replacement for on-campus, classroom-based education, nor is it viewed as a viable alternative to traditional education. It is seen as merely a means of continuing academic activity in the event of a pandemic. Education entails more than just classroom teaching and learning. It entails numerous factors. Students gain knowledge from their teachers, peers, seniors, the environment, activities, and programmes, among other sources. Moreover, there is more scope and freedom for students to connect with their teachers in the process of learning. In the case of online education, all of these are lacking. That is how the survey respondents saw it. $66 \%$ of respondents say they learn less online than they do in the classroom. $24 \%$ of students say they are learning about the same and only $10 \%$ of students believe they study substantially more in online mode than they do in classrooms. Figure-5 below showing the students' perspectives on learning during remote education compared to on-campus classes.

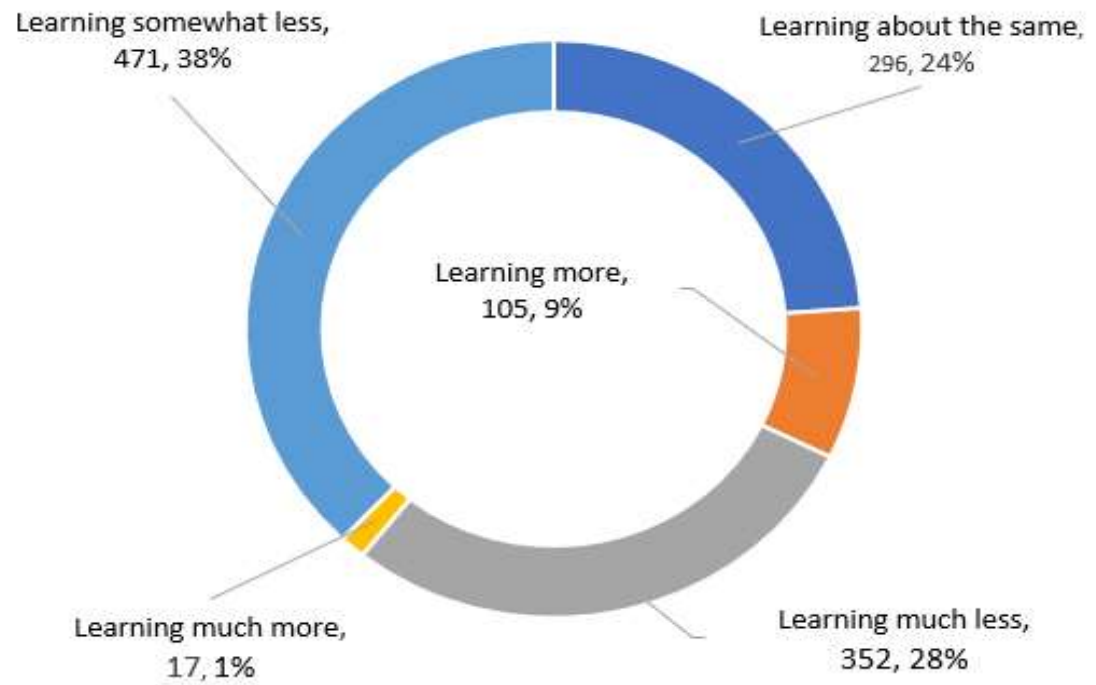

Fig. 5: Students' perspectives on learning during remote education compared to on-campus classes 
One of the most significant advantages of the conventional teaching-learning technique is the ability for students to express themselves during class. Though students can express themselves online, the opportunities are limited due to the technology involved. Students do not have the same freedom to express themselves as they have in the classroom because the teacher maintains the control or the situation will devolve into chaos. As a result, students in online education have fewer opportunities to express themselves. Only $32 \%$ of students feel that they always get the opportunity to express themselves in online classes. 30\% of students say they only sometimes get an opportunity, while $18 \%$ say they only get a chance once in a while. $20 \%$ of students believe they are never given the chance to express themselves. Students' perceptions of the opportunity to express themselves during online classes are presented below in Figure-6.

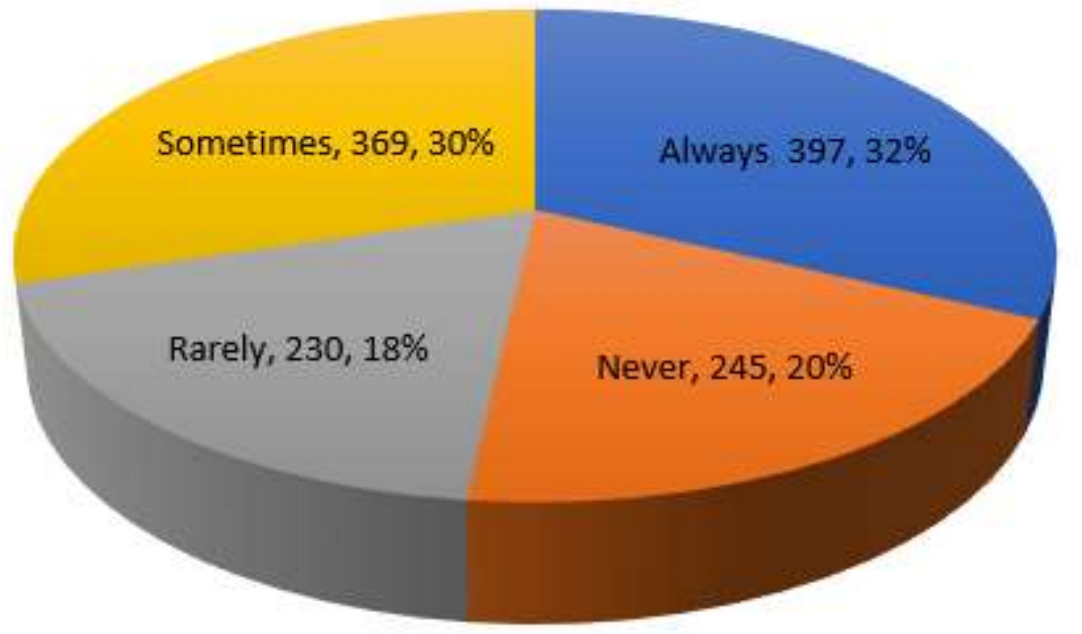

Fig. 6: Students' perceptions of the opportunity to express themselves during online classes Proponents of online education claim that this method allows students to learn more, gain more knowledge, discover new things, and think out of the box though they are at home. This is due to the online resources available, as well as the opportunities and exposure earned. According to the survey results, students are not convinced by this argument. Only $58 \%$ of respondents agree that online education has helped them learn new skills while at home, while $42 \%$ of students completely disagree. Table-13 below containing data on student's perspective on learning new things, though they are at home

Table 13: Student's perspective on learning new things, though they are at home

\begin{tabular}{|r|r|r|r|r|r|r|}
\hline Options & \multicolumn{1}{l}{ Female } & \multicolumn{1}{l|}{ Male } & \multicolumn{1}{l|}{ Total } & \multicolumn{1}{l|}{ l } \\
\hline Degree & 569 & 78.48 & 449 & 87.02 & 1018 & 82.03 \\
\hline Strongly Agree & 31 & 5.45 & 27 & 6.01 & 58 & 5.7 \\
\hline Agree & 326 & 57.29 & 208 & 46.33 & 534 & 52.46 \\
\hline Disagree & 177 & 31.11 & 152 & 33.85 & 329 & 32.32 \\
\hline Strongly disagree & 35 & 6.15 & 62 & 13.81 & 97 & 9.53 \\
\hline Post-Graduation & 150 & 20.69 & 62 & 12.02 & 223 & 17.97 \\
\hline Strongly Agree & 5 & 3.33 & 2 & 3.23 & 7 & 3.14 \\
\hline Agree & 94 & 62.67 & 29 & 46.77 & 123 & 55.16 \\
\hline Disagree & 47 & 31.33 & 24 & 38.71 & 71 & 31.84 \\
\hline Strongly disagree & 10 & 6.67 & 12 & 19.35 & 22 & 9.87 \\
\hline
\end{tabular}

The goal of education is to give students with meaningful theoretical and practical knowledge. Students acquire knowledge from their experiences. Experiments can be used to introduce new concepts or to clarify confusing aspects of topics that students struggle with regularly. Students will be able to take ownership of a new concept and use it to scaffold learning if the conclusion of an experiment is 
unexpected but intriguing. In addition to confirming that the experiment's conceptual focus has been correctly understood, post-experiment homework may require students to describe a follow-up experiment or apply the concept to another application. Classroom education provides a great opportunity to get both theoretical and practical experience. As per students' responses, the same is missing in online education. Table-14 shows students' responses to whether online education provided them with enough practical and theoretical experience. According to $72 \%$ of respondents, online classes did not provide enough theoretical and practical experience. PG students $(80 \%)$ are more concerned about the issue compare to UG students (70\%). In addition, when compared to male students $(75 \%)$, female students are slightly less concerned $(69 \%)$.

Table 14: Students' feedback on theoretical and practical experiences gained through online education

\begin{tabular}{|rr|r|r|r|r|r|r|}
\hline \multicolumn{1}{|l|}{ Options } & & UG & $\boldsymbol{\%}$ & PG & \% & $\begin{array}{r}\text { Grand } \\
\text { Total }\end{array}$ & \% \\
\hline Female & & $\mathbf{5 6 9}$ & $\mathbf{5 5 . 8 9}$ & $\mathbf{1 5 6}$ & $\mathbf{7 3 . 5 8}$ & $\mathbf{7 2 5}$ & $\mathbf{5 8 . 4 2}$ \\
\hline & No & $\mathbf{3 7 7}$ & 66.26 & $\mathbf{1 2 3}$ & 78.85 & 500 & 68.97 \\
\hline & Yes & $\mathbf{1 9 2}$ & 33.74 & $\mathbf{3 3}$ & 21.15 & 225 & 31.03 \\
\hline Male & & $\mathbf{4 4 9}$ & $\mathbf{4 4 . 1 1}$ & $\mathbf{6 7}$ & $\mathbf{3 1 . 6}$ & $\mathbf{5 1 6}$ & $\mathbf{4 1 . 5 8}$ \\
\hline & No & $\mathbf{3 3 4}$ & 74.39 & $\mathbf{5 5}$ & 82.09 & 389 & 75.39 \\
\hline & Yes & $\mathbf{1 1 5}$ & 25.61 & $\mathbf{1 2}$ & 17.91 & 127 & 24.61 \\
\hline
\end{tabular}

\section{TESTING OF HYPOTHESIS :}

Using the Chi-Square Test statistical model, the hypotheses were tested. The chi-squared test (symbolized as $\mathrm{X}^{2}$ ) is a data analysis based on random observations of a set of variables. It is typically a comparison of two sets of statistical data. By assuming that the null hypothesis is true, the chi-square test is used to determine how likely the observations are. The formula for chi-square can be written as:

$$
\chi^{2}=\sum(O-E)^{2} / E
$$

The observed frequency is denoted by the letter $\mathrm{O}$. E is the null hypothesis' expected frequency, which is calculated as follows:

$$
E=\frac{\text { row total } \times \text { column total }}{\text { sample size }}
$$

When the null hypothesis is true, the test statistic's sample distribution is known as the chi-squared distribution. The two category variables are independent under the Null Hypothesis. Hypothesis testing is a technique for rejecting a null hypothesis with a given level of confidence. The null hypothesis is tested with a p-value of .05 to see if there is evidence against it [36].

In one or more classes or categories, the chi-squared test can be used to see if there is a significant difference between the normal and observed frequencies. It expresses the likelihood of independent variables. Probability is represented by the letter $\mathrm{P}$ in this equation. The chi-square test is employed in statistics to compute the p-value [37].

The various $\mathrm{p}$ values that correspond to different hypothesis interpretations are given below: $\mathrm{P} \leq .05$; Hypothesis rejected

$\mathrm{P}>.05$; Hypothesis accepted

The online Chi-Square Test Calculator provided by Social Science Statistics (https://www.socscistatistics. com/ tests/chisquare2/default2.aspx) is used to perform the chi-square test with data samples.

$\mathrm{H}_{1}$ : Technology assisted online education is the perfect alternative to traditional classroom-based education in this COVID-19 Pandemic situation.

The observed cell totals, (anticipated cell totals), and [the chi-square statistic for each cell] are all listed in the contingency table (Table-15) below.

Table 15: The contingency table -1

\begin{tabular}{|l|l|l|r|}
\hline & \multicolumn{1}{|c|}{ UG } & \multicolumn{1}{c|}{ PG } & Row Totals \\
\hline Extremely Effective & $14(20.51)[2.07]$ & $11(4.49)[9.43]$ & 25 \\
\hline Very Effective & $85(77.93)[0.64]$ & $10(17.07)[2.93]$ & 95 \\
\hline
\end{tabular}




\begin{tabular}{|l|c|l|r|}
\hline Partially Effective & $205(210.00)[0.12]$ & $51(46.00)[0.54]$ & 256 \\
\hline Somewhat Effective & $541(520.89)[0.78]$ & $94(114.11)[3.54]$ & 635 \\
\hline Not at all Effective & $173(188.67)[1.30]$ & $57(41.33)[5.94]$ & 230 \\
\hline Total & $\mathbf{1 0 1 8}$ & $\mathbf{2 2 3}$ & $\mathbf{1 2 4 1}$ \\
\hline
\end{tabular}

The calculated chi-square statistic is 27.2864 and the p-value is .000017 . Therefore, the result is significant at $\mathrm{p}<.05$. Hence the null hypothesis is rejected.

$\mathbf{H}_{2}$ : Both male and female students are equally satisfied with online education.

The observed cell totals, (anticipated cell totals), and [the chi-square statistic for each cell] are all listed in the contingency table (Table-16) below.

Table 16: The contingency table-2

\begin{tabular}{|c|c|c|c|}
\hline & Female & Male & Row Totals \\
\hline Excellent & $17(15.77)[0.10]$ & $10(11.23)[0.13]$ & 27 \\
\hline Good & $251(208.56)[8.64]$ & $106(148.44)[12.13]$ & 357 \\
\hline Average & $338(316.64)[1.44]$ & $204(225.36)[2.02]$ & 542 \\
\hline Not Interesting & $76(99.32)$ [5.47] & $94(70.68)$ [7.69] & 170 \\
\hline Poor & 43 (84.71) [20.54] & $102(60.29)[28.86]$ & 145 \\
\hline Total & 725 & 516 & 1241 \\
\hline
\end{tabular}

The chi-square statistic is 87.0202 . The $p$-value is $<0.00001$. The result is significant at $p<.05$. Hence the null hypothesis is rejected.

$H_{3}$ : Students were not stressed while learning remotely during the COVID-19 pandemic.

The observed cell totals, (anticipated cell totals), and [the chi-square statistic for each cell] are all listed in the contingency table (Table-17) below

Table 17: The contingency table-3

\begin{tabular}{|l|l|l|r|}
\hline & \multicolumn{1}{|c|}{ Female } & \multicolumn{1}{c|}{ Male } & Row Totals \\
\hline Extremely stressful & $49(67.77)[5.20]$ & $67(48.23)[7.30]$ & 116 \\
\hline Very stressful & $112(120.93)[0.66]$ & $95(86.07)[0.93]$ & 207 \\
\hline Moderately stressful & $232(220.83)[0.57]$ & $146(157.17)[0.79]$ & 378 \\
\hline Slightly stressful & 256(240.69) [0.97] & 156(171.31) [1.37] & 412 \\
\hline Not at all stressful & $76(74.78)[0.02]$ & $52(53.22)[0.03]$ & 128 \\
\hline \multicolumn{1}{|c|}{ Total } & $\mathbf{7 2 5}$ & $\mathbf{5 1 6}$ & $\mathbf{1 2 4 1}$ \\
\hline
\end{tabular}

The chi-square statistic is 17.8348 . The $\mathrm{p}$-value is .001329 . The result is significant at $\mathrm{p}<.05$. Hence the null hypothesis is rejected.

$\mathrm{H}_{4}$ : Students believe they gain enough theoretical and practical experience from online education. The observed cell totals, (anticipated cell totals), and [the chi-square statistic for each cell] are all listed in the contingency table (Table-18) below

Table 18: The contingency table-4

\begin{tabular}{|l|c|c|r|}
\hline \multicolumn{1}{|c|}{ Male } & Female & \multicolumn{1}{c|}{ Row Totals } \\
\hline Yes & $389(369.64)[1.01]$ & $500(519.36)[0.72]$ & 889 \\
\hline No & $127(146.36)[2.56]$ & $225(205.64)[1.82]$ & 352 \\
\hline Total & $\mathbf{5 1 6}$ & $\mathbf{7 2 5}$ & $\mathbf{1 2 4 1}$ \\
\hline
\end{tabular}

The chi-square statistic is 6.1188. The p-value is .013375 . The result is significant at $p<.05$. Hence the null hypothesis is rejected [37-38].

\section{FINDINGS :}

The study's findings demonstrate that introducing online learning was a brilliant idea, as the majority of students surveyed supported it in this pandemic condition. They stated that online education assisted them in continuing their education while on-campus activities were prohibited due to lockdown and the 
spread of viruses. Students' impressions of technology-assisted online education as a viable alternative to traditional classroom-based education amid the COVID-19 pandemic are another finding from the study. The study also discovered that there is a gender gap in terms of satisfaction with online education and that private institutions outperform state-sponsored institutions in terms of online education. Last but not least, the study discovered that the greatest barrier to students engaging in online education was inadequate internet access in the rural as well suburban areas. After interpreting and analyzing survey data we found that:

- When participating in online education, a large number of students use mobile data to connect their devices to the internet. Their main barrier to participation is believed to be the network itself.

- Students are self-reliant in terms of the devices they use to take online classes, with a substantial proportion of students using their smartphones to attend online classes.

- Teachers employ mixed modes to assess students' progress during online education. Their options include writing examinations offline and uploading scanned response scripts, online quizzes, exams using dedicated exam software, writing the test in front of a live camera, and then uploading the scanned responses, and open book exams.

- Students are satisfied with online education in this pandemic condition. Furthermore, female students find online education more convenient than male students.

- Teachers in online education do not prefer synchronous delivery methods, such as live classes.

- In comparison to male students, female students spend more time on online education activities.

- The frequency with which students receive study materials from their lecturers has increased in online education.

- A significant proportion of students are completely or partially happy with the effectiveness of online education during this pandemic.

- Students are not convinced that online education would improve their learning experience.

- Students are not fully satisfied with the technologies and applications that teachers employ for online education delivery.

- Students believe that face-to-face communication is critical to the success of online learning.

- Students were more stressed when learning online in this pandemic circumstance.

- Students believe their parents are supportive in every way throughout online education amid the pandemic

- A large number of students are taking on the role of active learners in online education.

- Students believe they learn less in online education than they do in on-campus education.

- In comparison to on-campus classes, students felt they had less opportunity to express themselves in online classrooms.

- Students believe that online education did not give them enough practical and theoretical experience.

\section{RECOMMENDATIONS :}

While the haphazard and hasty move to online education - with minimal training, insufficient bandwidth, and little planning - is expected to result in a bad student experience that will stymie longterm growth. Simultaneously, a new hybrid model of education with significant benefits has the potential to emerge. This is a hybrid of online and on-campus learning. It is projected that the integration of information technology into education will continue to grow, with online education being a common aspect of education in the future. The following recommendations have been made for the successful implementation of online education and to improve its efficacy.

- Excessive use of technology, as well as time spent in front of screens and using devices, has been related to health problems, hence it is recommended that online education activities be limited to 3-4 hours a day.

- The goal of education is to improve students' theoretical and practical knowledge of the subject and to prepare them academically for the next step. Education providers are recommended to use virtual platforms such as virtual classrooms, virtual labs, and virtual libraries to bridge the learning gap since students believe online education provides them with insufficient practical and theoretical experience. 
- The efficiency with which technology and software tools are employed to deliver online education is dependent on how well they are utilized. If teachers employ open and free software tools and user-friendly technology, students would be able to cope better with education rather than technological impediments. In this context, it is recommended that education providers make full use of free and open-source online resources to deliver online education more effectively and interactively.

- It is tremendously good for students' social skills and classroom behavior management to encourage them to communicate their feelings. Students begin to recognize and comprehend their own emotions, which can aid in the development of their autonomous thinking. Teachers must provide additional possibilities for students to express themselves in virtual classrooms in this regard. To realize that conducting online classes for small groups of students rather than a big audience is encouraged.

- Students perceive that online education provides them with fewer learning opportunities than on-campus education. To address this, teachers must make full use of a variety of educational resources and provide learning materials in both online and offline formats so that students receive the most input possible to achieve their learning objectives.

- Teachers may lack experience creating digital content and communicating it successfully online. It's unfair to expect them to improve and students to adjust all of a sudden, just to discover the dreadful and unpleasant later. In this respect, it is recommended that sufficient training and orientation programmes be provided for both teachers and students for them to acclimate to the online environment without undue stress or discomfort.

- It is recommended to adopt synchronous methods of education delivery on the internet, such as live classes using live meeting platforms like Google Meet, Zoom, and others, to achieve faceto-face and interactive education.

- One of the greatest obstacles to the effective continuation of online education is the internet connection, speed, stability, and availability. In this regard, the state must assess the current situation and resolve the issues so that students and teachers have access to a consistent and stable internet connection at their location.

\section{DISCUSSION :}

Online education is a must in this epidemic situation. It has allowed students to receive instruction without having to travel, and it is more flexible. It is likely providing a nice break from their hectic schedules and long commutes to class. Others may find this to be a less stressful option if they are uncomfortable learning in large groups. Many educators are taking advantage of the circumstance by experimenting with novel teaching and assessment approaches. This gives hope. However, once online education becomes the only method of learning, and that for an extended time, the good, bad, and ugly parts of online education begin to emerge.

Teachers may lack experience in developing digital content and effectively communicating it online. It's unjust to ask them to improve and students to adjust all of a sudden and that, with time, the terrible and the unpleasant become apparent. In an online class, body language and eye contact, which are essential teacher indications, are hard to trace. The lack of continuous feedback in the form of student responses during online sessions, which limits teaching efficacy. Is it difficult for a teacher to determine how many students in a class have paid attention? How many of them were able to grasp the lesson? Is the class going at a good pace? Is it true that some students are falling behind? These concerns arise in traditional classrooms as well, but they are more difficult to solve in online courses. Even students appear to place a higher value on an in-class physical learning experience than a virtual one. Phones are considered to be a major source of distraction by students. In addition, to complement theoretical study, science and technology programmes frequently incorporate hands-on laboratory sessions, dissertation projects, and field trips. In online education, this component of learning is severely constrained. Furthermore, education entails not just topic knowledge but also the development of social skills and sportsmanship among students through time. Students' overall development may be hampered if they rely entirely on online education, and many may underperform later in their career and personal life.

While India has a diverse physical and cultural landscape, it also has a significant socioeconomic difference. At the moment, only a small portion of India's population has access to online education. Power outages, poor or non-existent internet connections, and the inability to afford necessary devices 
are all serious challenges. To address concerns with internet access and device availability, many teachers are sharing videos with students via WhatsApp or YouTube so that they can watch them whenever they choose. However, this, too, is associated with difficulty in comprehending the lessons and encourages rote learning. Pre-recorded sessions broadcast on television and radio are similar, though they serve a larger student base who cannot attend live online classes. And that's not all. When a family's income is limited, the girls are often the first to suffer. Male adults almost usually had smartphones, which were often less accessible to girls than boys, and many families couldn't afford internet data packages. Students with disabilities are among the most reliant on face-to-face instruction, and so are unlikely to benefit from distant learning. Furthermore, a lack of adequate online education may exacerbate students' school dropout rates.

During the pandemic, there is widespread understanding of the need for inclusive education policies. The Government of India has developed many online resources, training programmes, and initiatives for students, instructors, and educational institutions to make online education more effective, accessible, and secure. The teaching community has banded together to form the Discussion Forum of Online Education (DFOT), a statewide information and volunteer network of teachers dedicated to discussing various elements of online teaching and creating resource libraries.

Artificial intelligence (AI) and other cutting-edge technology may open up new opportunities for innovative and individualized learning approaches that cater to a variety of learning abilities. The National AI Resource Platform (NAIRP) was developed by IIT Kharagpur in collaboration with Amazon Web Services, and its future capabilities include tracking eye movement, mobility, and other factors for improved teaching and learning. Google has also stated that it will promote AI-based education in India in the future. For both students and teachers, online education offers a wealth of opportunities. However, it has the potential to exacerbate social inequities. Inclusion should be a goal of all policies and activities relating to online education.

\section{CONCLUSION :}

Online education is the only way to keep up with education in this epidemic situation. Thanks to Internet and web technologies. The entire academic year went by with few academic events on campus. Educators give education from their places of work and residence via online platforms. At the same time, students participate in the learning process from the comfort of their own homes. Online education allows students to receive instruction without having to travel, and it is also more flexible. Many teachers are taking advantage of the situation by trying out new teaching and assessment methods. This instills hope. However, as online education becomes the exclusive mode of instruction for an extended length of time, the good, bad, and ugly aspects of online education become apparent. Even though teachers and students have become accustomed to online learning in this pandemic situation, they appear to be dissatisfied with how it is proceeding. On-campus classroom-based education, students say, is more effective and convenient than online learning. They strongly believe they learn less and are more stressed when learning online. The data gathered in this study drew attention to this. A new hybrid form of education has the potential to emerge, with significant benefits. This is a hybrid of online and on-campus learning. It is projected that the integration of information technology into education will continue to grow, with online education being a common aspect of education in the future.

\section{Acknowledgment:}

We thank all of the undergraduate and postgraduate students who took part in the survey. Prof. Ganapathy S., Former HoD., Dept of Economics, St Philomena College, Puttur, and Prof Shashidhar Kotian, Professor, Research, Srinivas University, Mangalore, for assistance with survey design and statistical analysis. All respondents to the survey used in this study provided their permission for their responses to be evaluated as part of the study.

\section{REFERENCES :}

[1] Johnson, N., Veletsianos, G. \& Seaman, J. (2020). U.S. Faculty and Administrators' Experiences and Approaches in the Early Weeks of the COVID-19 Pandemic, Online Learning Journal, 24(2), $6-21$. 
[2] Geetha Poornima, K, Rajeshwari, M, Vinayachandra, \& Krishna Prasad, K. (2020). Integration of Adaptive Technologies with Healthcare for the Early Identification and Control of COVID-19 Pandemic Disease. International Journal of Health Sciences and Pharmacy (IJHSP), 4(2), 5-28.

[3] Krishna Prasad, K., Aithal, P. S., Geetha Poornima, K., \& Vinayachandra, (2021). An AI-based Analysis of the effect of COVID-19 Stringency Index on Infection rates: A case of India. International Journal of Health Sciences and Pharmacy (IJHSP), 5(1), 87-102.

[4] Krishna Prasad, K., Vinayachandra, Geetha Poornima, K. \& Rajeshwari, M. (2020). Effect of COVID-19 on Technology Penetration: a Predictive Analysis. Alochana Chakra Journal, 9(5), 2949-2967.

[5] Elena Silva \& Taylor White (2015). The Carnegie Unit: Past, Present, and Future, Change: The Magazine of Higher Learning, 47(2), 68-72.

[6] Dunlap, J., \& Lowenthal, P. (2018). Online educators' recommendations for teaching online: Crowdsourcing in action. Open Praxis, 10(1), 79-89.

[7] Mason, R. (2000). From distance education to online education. The Internet and Higher Education, 3(1), 63-74.

[8] Zapalska, A., \& Brozik, D. (2006). Learning styles and online education. Campus-Wide Information Systems, 23(5), 325-335.

[9] Kariya, S. (2003). Online education expands and evolves. IEEE Spectrum, 40(5), 49-51.

[10] Doyumgaç et al. (2021). Understanding the Most Important Facilitators and Barriers for Online Education during COVID-19 through Online Photovoice Methodology. International Journal of Higher Education, 10(1), 166-190.

[11] Paudel, P. (2021). Online education: Benefits, challenges, and strategies during and after COVID19 in higher education. International Journal on Studies in Education, 3(2), 70-85.

[12] Doyle, W. R. (2009). Online Education: The Revolution That Wasn't. Change. The Magazine of Higher Learning, 41(3), 56-58.

[13] Finch, D., \& Jacobs, K. (2012). Online Education: Best Practices to Promote Learning. Proceedings of the Human Factors and Ergonomics Society Annual Meeting, 56(1), 546-550.

[14] Cook, C. W., \& Sonnenberg, C. (2014). Technology And Online Education: Models for Change. Contemporary Issues in Education Research (CIER), 7(3), 171-188.

[15] Kurzman, P. A. (2013). The Evolution of Distance Learning and Online Education. Journal of Teaching in Social Work, 33(4), 331-338.

[16] Sun, H., Wang, X., \& Wang, X. (2018). Application of Blockchain Technology in Online Education. International Journal of Emerging Technologies in Learning, 13(10), 253-259.

[17] Stewart, C., Bachman, C., \& Johnson, R. (2010). Predictors of faculty acceptance of online education. MERLOT Journal of Online Learning and Teaching, 6(3), 597-616.

[18] Heberling, M. (2002). Maintaining academic integrity in online education. Online Journal of Distance Learning Administration, 5(1), 1-7.

[19] Picciano, A. G. (2017). Theories and frameworks for online education: Seeking an integrated model. Online Learning, 21(3), 166-190.

[20] Aithal, P. S., \& Aithal, S. (2015). An innovative education model to realize ideal education system. International Journal of scientific research and management (IJSRM), 3(3), 2464-2469.

[21] Mukhtar K, Javed K, Arooj M, Sethi A (2020). Advantages, Limitations and Recommendations for online learning during COVID-19 pandemic era. Pakistan Journal of Medical Sciences, 36(4), 27-31.

[22] Szpringer, Monika et al. (2020). Students' perception of online learning during the COVID-19 pandemic : a survey study of Polish medical students. Research Square, 3(1), 1-14. 
[23] Chen, T., Peng, L., Yin, X., Rong, J., Yang, J., \& Cong, G. (2020). Analysis of user satisfaction with online education platforms in China during the COVID-19 pandemic. Healthcare. 8(3). 1-26.

[24] Doyumğaç, İ., Tanhan, A., \& Kiymaz, M. S. (2021). Understanding the Most Important Facilitators and Barriers for Online Education during COVID-19 through Online Photovoice Methodology. International Journal of Higher Education, 10(1), 166-190.

[25] Muthuprasad, T., Aiswarya, S., Aditya, K. S., \& Jha, G. K. (2021). Students' perception and preference for online education in India during COVID-19 pandemic. Social Sciences \& Humanities Open, 3(1), 1-11.

[26] Naik, G. L., Deshpande, M., Shivananda, D. C., Ajey, C. P., \& Patel, G. C. M. (2021). Online Teaching and Learning of Higher Education in India during COVID-19 Emergency Lockdown. Pedagogical Research, 6(1), 1-14.

[27] Ming, Y., Chung, P., Law, K. M. Y., Wu, C. H., Lau, Y., Guan, J., He, D., \& Ho, G. T. S. (2021). Comparative analysis of Student's live online learning readiness during the coronavirus (COVID19) pandemic in the higher education sector. Computers \& Education, 168(2), 104211.

[28] Bakhmat, L., Babakina, O., \& Belmaz, Y. (2021, March). Assessing online education during the COVID-19 pandemic: a survey of lecturers in Ukraine. Journal of Physics: Conference Series, $1840(1), 012050$.

[29] Fawaz, M. (2021). E-learning: Depression, anxiety, and stress symptomatology among Lebanese university students during COVID - 19 quarantine. Nursing forum, 56(1), 52-57.

[30] Ds, L., Jr, L., Tiangco, C. E., Angela, D., Sumalinog, G., Sabarillo, N. S., \& Mark, J. (2021). An effective blended online teaching and learning strategy during the COVID-19 pandemic. Education for Chemical Engineers, 35(2), 116-131.

[31] Picciano, A. G. (2015). Planning for online education: A systems model. Online Learning, 19(5), $142-158$

[32] Volery, T. (2001). Online Education: An Exploratory Study into Success Factors. Journal of Educational Computing Research, 24(1), 77-92.

[33] Mortagy, Y., \& Boghikian-Whitby, S. (2010). A longitudinal comparative study of student perceptions in online education. Interdisciplinary Journal of E-Learning and Learning Objects, 6(1), 23-44.

[34] Bao, W. (2020). COVID-19 and online teaching in higher education: A case study of Peking University. Human Behavior and Emerging Technologies, 2(2), 113-115.

[35] Chen, T., Peng, L., Jing, B., Wu, C., Yang, J., \& Cong, G. (2020). The impact of the COVID-19 pandemic on user experience with online education platforms in China. Sustainability, 12(18), 7329.

[36] Rana R, Singhal R. (2015). Chi-square test and its application in hypothesis testing. Journal of Practice of Cardiovascular Sciences, 1(1), 69-71.

[37] McHugh M. L. (2013). The chi-square test of independence. Biochemia medica, 23(2), 143-149. 